\title{
Väkivalta- ja uhkatilanteet maataloustukivalvonnoissa ja tarkastajien työssä jaksaminen
}

\author{
Ritva Vaittinen $^{1,2}$, Kalevi Paldanius ${ }^{1}$ ja Maija Puurunen ${ }^{2}$ \\ 1) Savonia-ammattikorkeakoulu,PL 7274101 Iisalmi, etunimi.sukunimi@savonia.fi \\ 2) Etelä-Savon TE-keskus, Mikonkatu 3 ja 550100 Mikkeli, etunimi.sukunimi@,te-keskus.fi
}

\section{Tiivistelmä}

Maataloustukien valvontaa tekevät pääsääntöisesti työvoima- ja elinkeinokeskusten tarkastajat. Tässä työssä keskityttiin maataloustukivalvojien työhön ja heidän hyvinvointiinsa. Tutkimuksessa haluttiin selvittää, missä määrin ja millaista väkivaltaa tai sen uhkaa tarkastajat ovat työssään kohdanneet ja miten työnantajat ovat hoitaneet tarkastajien työturvallisuuden. Lisäksi selvitettiin, miten tarkastajat jaksavat työssään ja mitkä tekijät vahvistavat työssä jaksamista.

Tutkimus toteutettiin vuosina 2007-2008. Tutkimusaineisto kerättiin kyselyllä, joka suunnattiin kaikille työvoima- ja elinkeinokeskusten maataloustukivalvontaa tekeville tarkastajille. Kysely toteutettiin tammikuun 2008 aikana. Kyselyn vastausprosentti oli 73 ja kohderyhmän koko 268 (N=268).

Tämän tutkimuksen mukaan maataloustukivalvojien työhön liittyy turvallisuusriskejä. Joka viides (21 \%) tarkastaja oli kohdannut jonkinlaista väkivaltaa tai sen uhkaa työssään. Väkivallan tai sen uhkan uhreista naisia oli $43 \%$ ja miehiä $57 \%$. Kolme neljäsosaa (72\%) tarkastajista oli joutunut verbaalisen väkivallan kohteeksi. Lähes puolella (46 \%) tarkastajista oli ongelmia työssä jaksamisessa. Työssä jaksamista vahvistavista tekijöistä nousivat selvästi esille työilmapiiri, työkaverit sekä perhe ja vapaa-aika.

Tässä tutkimuksessa selvitettiin myös vaaratilanteiden jälkihoitoa työpaikoilla. Tutkimuksen mukaan työpaikoilla ei ole hoidettu vaaratilanteiden jälkihoitoa kunnolla. Kaikilla työpaikoilla ei ole myöskään laadittu riittäviä turvallisuusohjeita tarkastajille.

Tutkimuksessa saatuja tuloksia voidaan hyödyntää valvontatyön kehittämisessä ja tarkastajien kouluttamisessa sekä heidän työhyvinvointinsa parantamisessa. Tutkimuksen tulosten pohjalta on laadittu tarkastajien turvallisuusohjeet Etelä-Savon työvoima- ja elinkeinokeskukselle, joka toimi tämän tutkimuksen toimeksiantajana.

Asiasanat: maataloustuki, valvonta, tarkastaja, väkivalta, työturvallisuus, jaksaminen 


\section{Johdanto}

Suomalaisille viljelijöille maksetaan maataloustukia sekä Euroopan Unionin (EU) rahastoista että kansallisista varoista. Viljelijätukijärjestelmän perusta muodostuu EU:n yhteisen maatalouspolitiikan mukaisista tukimuodoista. Näistä tuista tärkeimmät ovat EU:n kokonaan rahoittamat tuet (ns. suorat tuet) sekä EU:n osarahoitteiset luonnonhaittakorvaus ja maatalouden ympäristötuki. Viljelijätuet maksetaan pinta-alaa, eläintä/eläinyksikköä tai tuotettua määrää kohden ja niiden tarkoituksena on turvata tuotannon kannattavuus ja jatkuvuus (Maaseutuvirasto 2008, Viljelijätuet.)

Viljelijätukien valvonnalla halutaan varmistaa, että viljelijät saavat tuet mahdollisimman oikeudenmukaisin ja tasapuolisin perustein koko maassa. Valvottavat tilat valitaan satunnaisella otannalla tai riskianalyysiin perustuen, joten mikä tahansa tila voi tulla valvotuksi. Vuosittain valvotaan vähintään viisi prosenttia tiloista (Hakuopas 2008, 111.)

Maataloustukien valvonnasta Suomessa vastaa nykyään keväällä 2007 perustettu Maaseutuvirasto (MAVI), joka on delegoinut käytännön tarkastustyön 15 työvoima- ja elinkeinokeskusten (TE-keskusten) maaseutuosaston vastuulle. TE-keskuksissa maataloustukien valvontaa tekevät TE-keskusten maaseutuosastojen tukitarkastajat. TE-keskusten maaseutuosastojen valvontatehtävissä vuonna 2006 olleiden henkilöiden määrä oli 405 henkilöä, ja valvontaan käytettiin työaikaa 206 henkilötyövuotta. Maataloustukivalvontoja arvioidaan vuonna 2007 tehdyn 32825 kappaletta. (Yhteenvetotiedot TE-keskusten maaseutuosastojen valvontasuunnitelmista 2007.)

Maaseutuosastojen valvojat tarkastavat tuen myöntämisen edellytysten täyttymisen ja tuen maksun oikeellisuuden. Valvonta tehdään virkavastuulla, kuten siitä Euroopan yhteisön yhteisen maatalouspolitiikasta

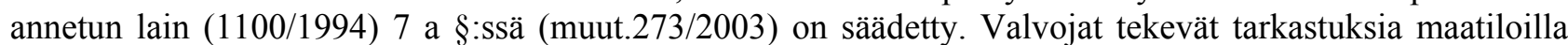
tarkastaen viljelyksiä, kotieläimiä, rakennuksia, koneita ja asiakirjoja. Työssään he joutuvat menemään yrittäjän työpaikalle ja kotiin - toisen reviirille. Tarkastuksen kohteena on viljelijän elinkeino ja työ ja siitä saatava palkka. Jo nämä seikat tekevät työn luonteesta sellaista, että se saattaa aiheuttaa asiakkaiden aggressiivista käyttäytymistä tarkastajaa kohtaan.

Tämän tutkimuksen tutkimusongelmina oli selvittää:

1) Missä määrin maataloustukivalvojat ovat kohdanneet työssään väkivaltaa tai sen uhkaa ja millaista väkivalta tai sen uhka ovat olleet? Miten valvojat ovat omasta mielestään selvinneet kokemastaan?

2) Miten tukivalvojien työpaikoilla TE-keskuksissa on hoidettu työturvallisuuslain edellyttämät toimenpiteet työntekijöiden kohtaamissa väkivalta- ja uhkatilanteissa ja tilanteiden jälkihoidossa?

3) Onko maataloustukivalvojilla ongelmia työssä jaksamisessa ja mitkä ovat mahdolliset syyt jaksamisongelmiin? Millä asioilla työssä jaksamista voidaan edistää ja ylläpitää?

Tutkimuksen tulokset voivat osaltaan edistää valvojien työturvallisuuden parantamista. Työn tarkoituksena oli edistää maataloustukivalvojien työturvallisuutta ja työssä jaksamista. Tutkimuksessa saatujen tulosten pohjalta laadittiin ohjeistusta valvontatyöhön

\section{Aineisto ja menetelmät}

Tutkimuksen kohderyhmänä olivat kaikkien TE-keskusten maaseutuosastojen maataloustukitarkastajat sekä vakinaiset että kesällä 2007 tilapäisenä olleet valvojat. Tällaisia henkilöitä oli 268. Tutkimusaineisto kerättiin kaikilta maataloustukivalvontaa tekeviltä henkilöiltä sähköisellä kyselylomakkeella. Koko kohderyhmän osallistumisen perusteella kyseessä oli kokonaistutkimus. Kyselyyn vastasi 196 henkilöä, jolloin vastausprosentiksi muodostui 73. Kysely valvojille toteutettiin tammikuussa 2008.

Kysely oli internet-pohjainen ja se toteutettiin käyttäen Digium Oy:n kyselytyökalua.

Tutkimuksessa on yhdistetty määrällinen ja laadullinen tutkimusmenetelmä. Tässä tutkimuksessa oli kyse retrospektiivisestä poikkileikkaustutkimuksesta, jossa tutkittavat arvioivat kokemaansa väkivalta- tai uhkatilannetta. Tässä tutkimuksessa hypoteeseja ei asetettu, koska aikaisempia tutkimuksia ei ole valvojien kohtaamasta väkivallasta ja sen uhkasta.

\section{Tulokset ja tulosten tarkastelu}

Tutkimuksessa selvitettiin, missä määrin maataloustukivalvojat olivat joutuneet valvontatyössä erilaisiin väkivalta- tai uhkatilanteisiin. Määrälliset tulokset on esitetty taulukossa 1. Tutkimusraportissa on kyselyn tuloksia myös tarkasteltu taustamuuttujien kuten ikä ja sukupuoli jne. suhteen. 
TAULUKKO 1. Tarkastajien kohtaamat väkivalta- ja uhkatilanteet

\begin{tabular}{|c|c|c|c|c|}
\hline Väkivalta- tai uhkatilanne & $\begin{array}{l}\text { Ei } \\
\text { kertaakaan }\end{array}$ & Kerran & 2-5 kertaa & $\begin{array}{l}\text { Yli viisi } \\
\text { kertaa }\end{array}$ \\
\hline $\begin{array}{l}\text { Nimittelyä, epäasiallista kielenkäyttöä, } \\
\text { sanallista uhkailua }(n=196)\end{array}$ & $\begin{array}{l}54 \\
27,6 \%\end{array}$ & $\begin{array}{l}31 \\
15,8 \%\end{array}$ & $\begin{array}{l}72 \\
36,7 \%\end{array}$ & $\begin{array}{l}39 \\
19,9 \%\end{array}$ \\
\hline Lyöntejä, kiinnikäymistä (n=194) & $\begin{array}{l}187 \\
96,4 \%\end{array}$ & $\begin{array}{l}7 \\
3,6 \%\end{array}$ & $\begin{array}{l}0 \\
0 \%\end{array}$ & $\begin{array}{l}0 \\
0 \%\end{array}$ \\
\hline Seksuaalista ahdistelua $(\mathrm{n}=194)$ & $\begin{array}{l}182 \\
93,8 \%\end{array}$ & $\begin{array}{l}9 \\
4,6 \%\end{array}$ & $\begin{array}{l}3 \\
1,5 \%\end{array}$ & $\begin{array}{l}0 \\
0 \%\end{array}$ \\
\hline $\begin{array}{l}\text { Puukolla tai muulla välineellä uhkailua } \\
(\mathrm{n}=195)\end{array}$ & $\begin{array}{l}177 \\
90,8 \%\end{array}$ & $\begin{array}{l}15 \\
7,7 \%\end{array}$ & $\begin{array}{l}3 \\
1,5 \%\end{array}$ & $\begin{array}{l}0 \\
0 \%\end{array}$ \\
\hline Aseellista uhkailua $(\mathrm{n}=195)$ & $\begin{array}{l}187 \\
95,9 \%\end{array}$ & $\begin{array}{l}7 \\
3,6 \%\end{array}$ & $\begin{array}{l}1 \\
0,5 \%\end{array}$ & $\begin{array}{l}0 \\
0 \%\end{array}$ \\
\hline Aseellista väkivaltaa $(\mathrm{n}=195)$ & $\begin{array}{l}195 \\
100 \%\end{array}$ & $\begin{array}{l}0 \\
0 \%\end{array}$ & $\begin{array}{l}0 \\
0 \%\end{array}$ & $\begin{array}{l}0 \\
0 \%\end{array}$ \\
\hline Puhelimessa uhkailua $(\mathrm{n}=194)$ & $\begin{array}{l}93 \\
47,9 \%\end{array}$ & $\begin{array}{l}33 \\
17 \%\end{array}$ & $\begin{array}{l}49 \\
25,3 \%\end{array}$ & $\begin{array}{l}19 \\
9,8 \%\end{array}$ \\
\hline Jokin muu $(n=40)$ & $\begin{array}{l}27 \\
67,5 \%\end{array}$ & $\begin{array}{l}10 \\
25 \%\end{array}$ & $\begin{array}{l}2 \\
5 \%\end{array}$ & $\begin{array}{l}1 \\
2,5 \%\end{array}$ \\
\hline
\end{tabular}

Väkivalta- ja uhkatilanteista vastaajat kertoivat tarkemmin avoimissa vastauksissa. Kuvailujen mukaan valvojien kohtaamat tilanteet olivat hyvinkin vaihtelevia ja vakavia, kuten seuraavista vastauksista ilmenee:

- Isäntä otti kauluksista kiinni ja oli tinttaamassa, ennen kuin ehdittiin päivää sanoa. Mutta ei lyönyt! Esimiehelle teki saman tempauksen seuraavalla valvontakäynnillä.

- Valvontatilanteessa isäntä taputteli pellolla takapuolelle ja piti kättä reidellä kun olimme autolla siirtymässä lohkolta seuraavalle ja teki samalla asiattomia ehdotuksia.

- Tarkastuksen jälkeen isäntä uhkasi pimeän tulle tulla kotiini kirveen kanssa kostamaan.

- Aseellisessa uhkailussa hirvikivääri oli nostettu keittiön tiskipöydällä, mikä ei varmaankaan ole sen normaali säilytyspaikka. Isäntä vielä kysyi pois lähtiessämme, että huomasimmeko kiväärin? Kertoen myös nostaneensa sen tarkoituksella esille.

- Puhelimessa teräaseella uhkailua, pyssyn käyttöön ottamista ja sen kanssa tulemista toimistolle.

- Traktorilla auton yliajo ja siihen liittyvät oikeudenkäynnit.

Vastaajien mukaan muina tilanteina mainittiin uhkauskirjeet, tappouhkaus, toiseen valvojaan kohdistuva uhkaus, itsemurhauhkaus, autolla ajon estäminen, auton vahingoittaminen ja koiralla uhkailu.

Kyselyssä tiedusteltiin myös, oliko vastaaja omasta mielestään joutunut valvontatyössä väkivallan tai sen uhkan uhriksi. Käsitettä "väkivallan tai sen uhkan uhri" ei vastaajalle tarkemmin määritelty, vaan annettiin vastaajan itse ratkaista oman subjektiivisen tuntemuksensa perusteella, oliko hän joutunut uhriksi. 21 prosenttia vastaajista eli 42 henkilöä kertoi joutuneensa väkivallan tai sen uhkan uhriksi.

Kaikista vastaajista laskettu väkivallan tai sen uhkan uhriksi joutuneiden määrä prosentteina oli 21. Taulukossa 2 on esitetty uhriksi joutuneiden vastaajien prosentuaalinen osuus kaikista vastaajista taustamuuttujien mukaan jaoteltuna. Tämän mukaan suurimmat väkivallan tai sen uhkan kohteeksi joutuneiden prosenttiosuudet olivat muun koulutuksen käyneillä tarkastajilla (44 \%), yli kuusi vuotta työkokemusta omaavilla (30 \%) ja vakituisessa työsuhteessa olevilla (29 \%) sekä Länsi-Suomen alueella (27\%) olleilla tarkastajilla. Se että nuoret eivät ole joutuneet väkivallan tai sen uhkan kohteeksi selittyy sillä, että heillä on vähän työkokemusta, jolloin heillä on pienempi todennäköisyys joutua kokemaan uhkatilanteita. Tilastollisia testauksia eroista ei tehty.

Tutkimuksessa selvitettiin tarkemmin, millaisia olivat nämä vaara- ja uhkatilanteet, jossa vastaaja oli omasta mielestään joutunut uhriksi. Vastauksia annettiin 53 tapauksen osalta. Yli puolet näistä (28 kpl) oli tapahtunut peltoalavalvonnan yhteydessä maatilalla, kuudessa tapauksessa oli kyse eläinvalvonnasta ja kuudessa tapausta oli ilmoitettu tapahtuneen muun valvonnan yhteydessä maatilalla tai neljässä tapauksessa vaaratilanne sattui asiakkaan käydessä toimistolla. 
TAULUKKO 2. Väkivallan tai sen uhkan uhriksi joutuneiden tarkastajien määrä ja heidän prosenttiosuus kaikista vastaajista taustatietojen mukaan $(\mathrm{n}=196)$

\begin{tabular}{|c|c|c|c|}
\hline Taustakysymys & Taustamuuttuja & $\begin{array}{l}\text { Uhrien } \\
\text { lukumäärä } \\
\text { henkilöä }\end{array}$ & $\begin{array}{l}\text { Prosenttia } \\
\text { kaikista }\end{array}$ \\
\hline Sukupuoli & $\begin{array}{l}\text { Nainen }(n=89) \\
\text { Mies }(n=107)\end{array}$ & $\begin{array}{l}18 \\
24\end{array}$ & $\begin{array}{l}20 \\
22\end{array}$ \\
\hline Ikä & $\begin{array}{l}\text { Alle } 25 \text { vuotta }(n=10) \\
25-35 \text { vuotta }(n=75) \\
\text { Yli } 35 \text { vuotta }(n=110)\end{array}$ & $\begin{array}{l}0 \\
17 \\
25\end{array}$ & $\begin{array}{l}0 \\
23 \\
23\end{array}$ \\
\hline Koulutus & $\begin{array}{l}\text { Ammattikoulu }(\mathrm{n}=13) \\
\text { Opistotason tutkinto }(\mathrm{n}=77) \\
\text { Alempi korkeakoulututkinto } \\
\text { /ammattikorkeakoulu }(\mathrm{n}=94) \\
\text { Ylempi korkeakoulututkinto }(\mathrm{n}=16) \\
\text { Muu koulutus }(\mathrm{n}=9)\end{array}$ & $\begin{array}{l}1 \\
17 \\
18 \\
3 \\
4\end{array}$ & $\begin{array}{l}8 \\
22 \\
19 \\
\\
19 \\
44\end{array}$ \\
\hline $\begin{array}{l}\text { TE-keskuksen } \\
\text { alue }\end{array}$ & $\begin{array}{l}\text { Etelä-Suomessa }(\mathrm{n}=55) \\
\text { Itä-Suomessa }(\mathrm{n}=34) \\
\text { Länsi-Suomessa }(\mathrm{n}=77) \\
\text { Pohjois-Suomessa }(\mathrm{n}=29)\end{array}$ & $\begin{array}{l}13 \\
6 \\
21 \\
2\end{array}$ & $\begin{array}{l}24 \\
18 \\
27 \\
7\end{array}$ \\
\hline Toimenkuva & $\begin{array}{l}\text { Esimies }(n=12) \\
\text { Tarkastaja }(n=172) \\
\text { Jokin muu }(n=16)\end{array}$ & $\begin{array}{l}3 \\
37 \\
2 \\
\end{array}$ & $\begin{array}{l}25 \\
22 \\
13\end{array}$ \\
\hline Työkokemus & $\begin{array}{l}\text { Alle } 1 \text { vuosi }(\mathrm{n}=15) \\
1-3 \text { vuotta }(\mathrm{n}=38) \\
3-6 \text { vuotta }(\mathrm{n}=52) \\
\text { Yli } 6 \text { vuotta }(\mathrm{n}=91)\end{array}$ & $\begin{array}{l}0 \\
5 \\
10 \\
27 \\
\end{array}$ & $\begin{array}{l}0 \\
21 \\
19 \\
30 \\
\end{array}$ \\
\hline Työsuhde & $\begin{array}{l}\text { Vakituinen }(n=134) \\
\text { Määräaikainen }(n=25) \\
\text { Määräaikainen kesätarkastaja }(n=37)\end{array}$ & $\begin{array}{l}39 \\
2 \\
1\end{array}$ & $\begin{array}{l}29 \\
8 \\
3\end{array}$ \\
\hline
\end{tabular}

Maataloustukivalvonnan asiakastyytyväisyyskyselyn 2006 mukaan TE-keskusten maaseutuosastojen tukivalvojat tekevät peltoalavalvontoja pääsääntöisesti pareittain. Eläinvalvontoja ja joitakin muita valvontoja tehdään enimmäkseen yksin. 53 väkivalta- ja uhkatilanteista seitsemän oli tapahtunut kun tarkastaja työskenteli yksin. Väkivalta- tai uhkatilanteen tapahtumapaikkana oli yhdeksässä tapauksessa asiakkaan asunto ja kahdessa tapauksessa tuotantorakennus. Yleisimmin vaaratilanne syntyi tarkastuskäynnin yhteydessä pihamaalla, pellolla tai metsässä (20 tapausta). 18 tapauksessa oli kyse jostakin muusta tilanteesta, joina vastaajat mainitsivat muun muassa peltoristiintarkastuksen, puhelinuhkauksen ja syytöksen virkavirheestä.

Vastaajat arvioivat kyselyssä väkivalta- ja uhkatilanteen vakavuutta. 53 tapahtuneesta tilanteesta 73 prosenttia (38) pidettiin vastaajien mielestä joko erittäin vakavana, melko vakavana tai vakavana ja 26 prosentin osalta (14) tapaukset eivät olleet erityisen vakavia. Yhden tilanteen osalta vastaaja oli valinnut vastausvaihtoehdon, en osaa sanoa

Työtekijän joutuessa vaara- tai uhkatilanteeseen on ensiarvoisen tärkeää, että tapahtuneesta kerrotaan. Kaikista kyselyn 53 väkivalta- tai uhkatilanteista oli kerrottu jollekin. Kolmesta tilanteesta ei oltu kerrottu esimiehelle. Työkavereille oli kerrottu 45 tapauksessa. Työterveyshuoltoon oltiin yhteydessä neljän tapauksen osalta. Poliisille tehtiin ilmoitus 16 tapauksen osalta. Läheiset ovat myös olleet tietoisia tapahtuneesta, sillä 23 tapauksen osalta tarkastaja kertoi tapahtuneesta läheisilleen.

Toisena tutkimusongelmana oli selvittää tarkastajien työsuojeluun liittyviä asioita. Työnantajat ovat velvollisia järjestämään työntekijöille vaara- ja uhkatilanteiden jälkihoitoa. Kyselyssä kysyttiin näiltä uhreilta, kuinka tyytyväisiä he olivat väkivalta- tai uhkatilanteen jälkeiseen apuun. Sekä fyysiseen että henkiseen apuun yli puolet vastaajista oli erittäin tyytyväisiä tai tyytyväisiä. Sen sijaan työnantajan toimintaan oltiin erittäin tyytymättömiä tai tyytymättömiä $18 \%$ :ssa tapauksista ja lähimmän esimiehen toimintaan $19 \%$ :ssa tapauksissa.

Valvontatyössä esiintyvän väkivallan tai sen uhkan ennaltaehkäisyä selvitettiin kyselyssä. Vastaajat asettivat tärkeimmiksi asioiksi työskentelyn pareittain, koulutuksen järjestämisen asiakkaan kohtaamisesta sekä asiakkaiden tukikoulutukset. Sen sijaan itsepuolustustaitojen hankintaa ei pidetty mitenkään tärkeänä. 
Kolmantena tutkimusongelmana tutkittiin maataloustukivalvojien työssä jaksamista. Kysyttäessä, onko sinulla ollut työssä jaksamisongelmia, vastaajista $46 \%$ vastasi kyllä, $47 \%$ ei ja $7 \%$ en osaa sanoa. Selvä yhteys työssä jaksamiseen oli sillä, oliko henkilö joutunut väkivallan tai sen uhkan uhriksi: $60 \%$ uhreiksi joutuneista vastasi kyllä, $26 \%$ ei ja $14 \%$ en osaa sanoa. Tarkastajilla (42 henkilöä), jotka tässä kyselyssä kertoivat joutuneensa väkivallan tai sen uhkan uhriksi, oli 60 prosentilla jaksamisongelmia ja 26 prosentilla ei ollut. 14 prosenttia vastasi tähän kysymykseen, en osaa sanoa.(Kuviot 1 ja 2).

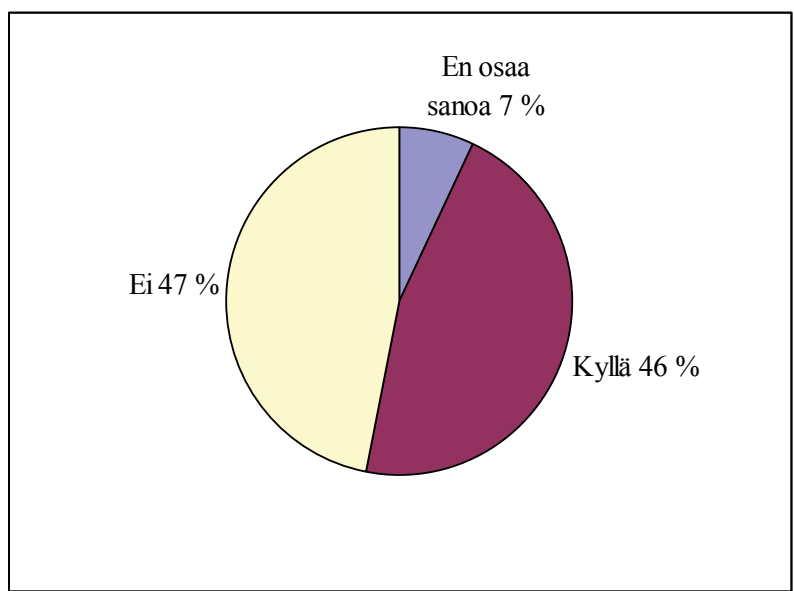

KUVIO 1. Jaksamisongelmien esiintyvyys kaikilla vastaajilla $(n=196)$

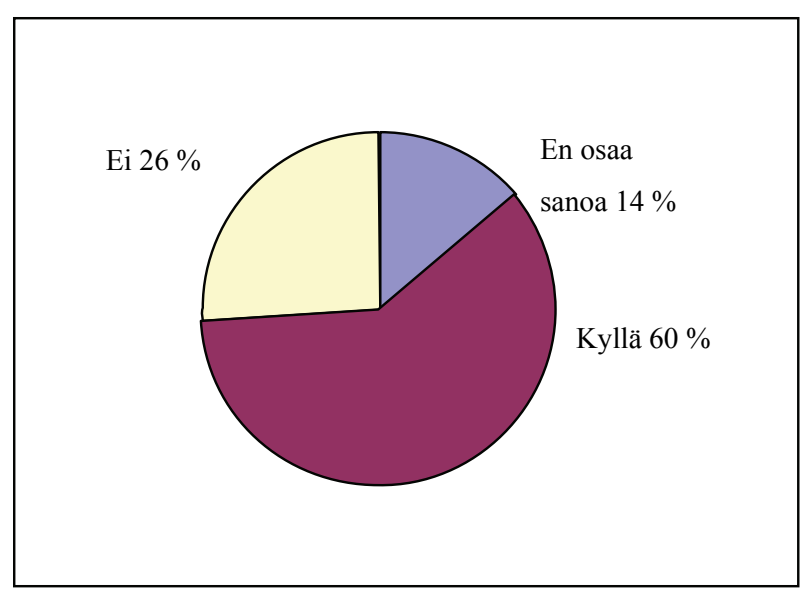

KUVIO 2. Jaksamisongelmien esiintyvyys väkivallan- tai sen uhkan uhreilla $(n=42)$

Yksin työskentely sekä peltoalavalvonnoilla (keskiarvo 2,79) että eläinvalvonnoilla (keskiarvo 2,68) koettiin työssä kuormittaviksi seikoiksi (ajatellen työssä jaksamista). Täydentävien ehtojen valvonta (ka 2,54) oli seuraaviksi kuormittavin asia. Hallinnollista valvontaa toimistotyönä eikä esimiestyötä /johtamista vastaajat eivät pitäneet mitenkään kuormittavana. (Kuvio 3.)

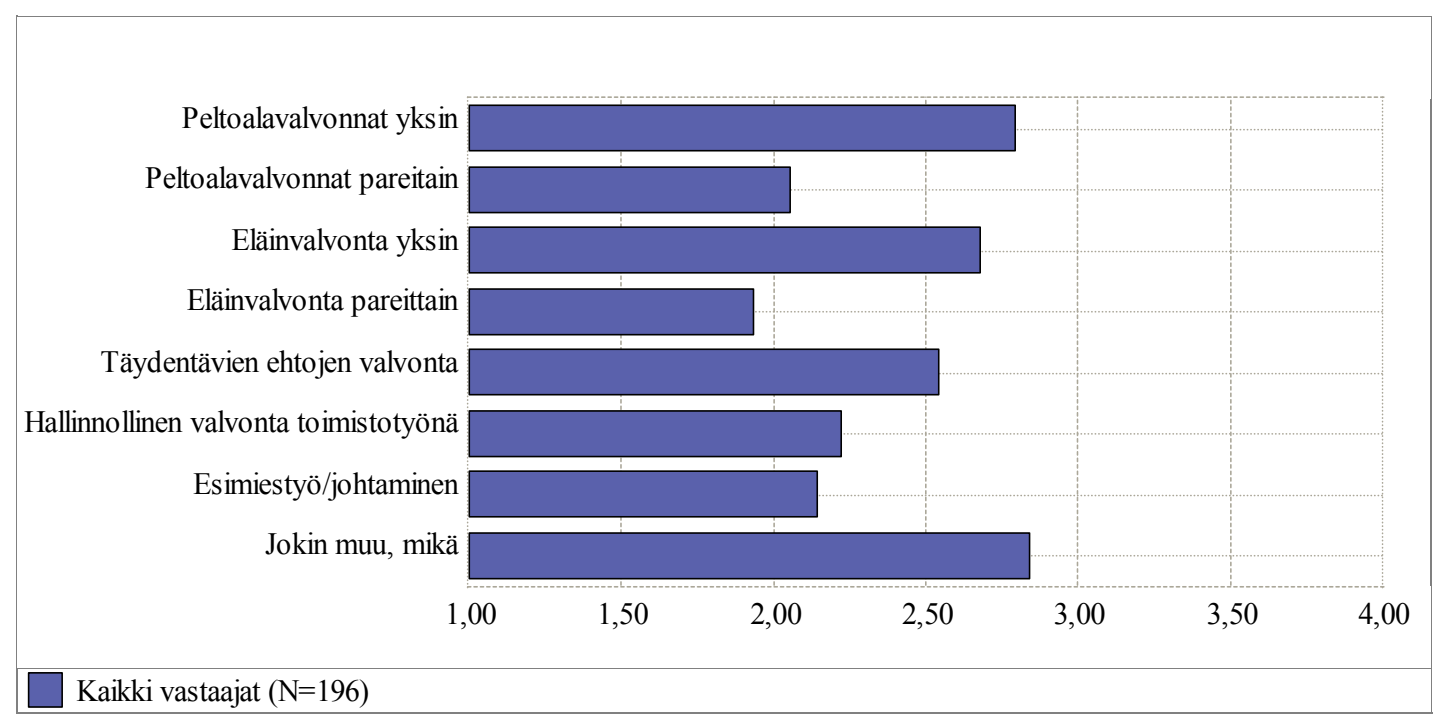

KUVIO 3. Eri valvontojen ja valvontamuotojen kuormittavuus

Vastaajia pyydettiin arvioimaan niitä asioita, jotka koetaan omasta mielestä tärkeiksi, kun ajatellaan omaa työssä jaksamista ja sen ylläpitämistä. Vastaajat arvioivat kysymyksessä asetettuja vaihtoehtoja asteikolla: erittäin tärkeä $(\operatorname{arvo}=4)$ - melko tärkeä $(\operatorname{arvo}=3)$ - ei kovin tärkeä $(\operatorname{arvo}=2)$ ja ei lainkaan tärkeä $(\operatorname{arvo}=1)$ sekä en osaa sanoa vaihtoehto $(\operatorname{arvo}=0)$. Kuten kuviosta 15 havaitaan tärkeimmiksi asioiksi, kun ajatellaan työssä jaksamista ja sen ylläpitämistä nousi työpaikan ilmapiiri (keskiarvo 3,8) ja työkaverit (keskiarvo 3,80). Perhettä ja vapaa-aikaa (keskiarvo 3,72) pidettiin kolmanneksi tärkeimpänä. Johtamista ja esimiehen tukea (keskiarvo 3,43) sekä työolosuhteita (keskiarvo 3,36) ja oman ammattitaidon kehittämistä 3,37) 
pidettiin seuraaviksi tärkeimpinä. Asiakkaita (keskiarvo 3,13) pidettiin vertailussa vähiten tärkeimpänä. Kaikki kysymyksessä esitetyt vaihtoehdot koettiin tärkeiksi (kuvio 4).

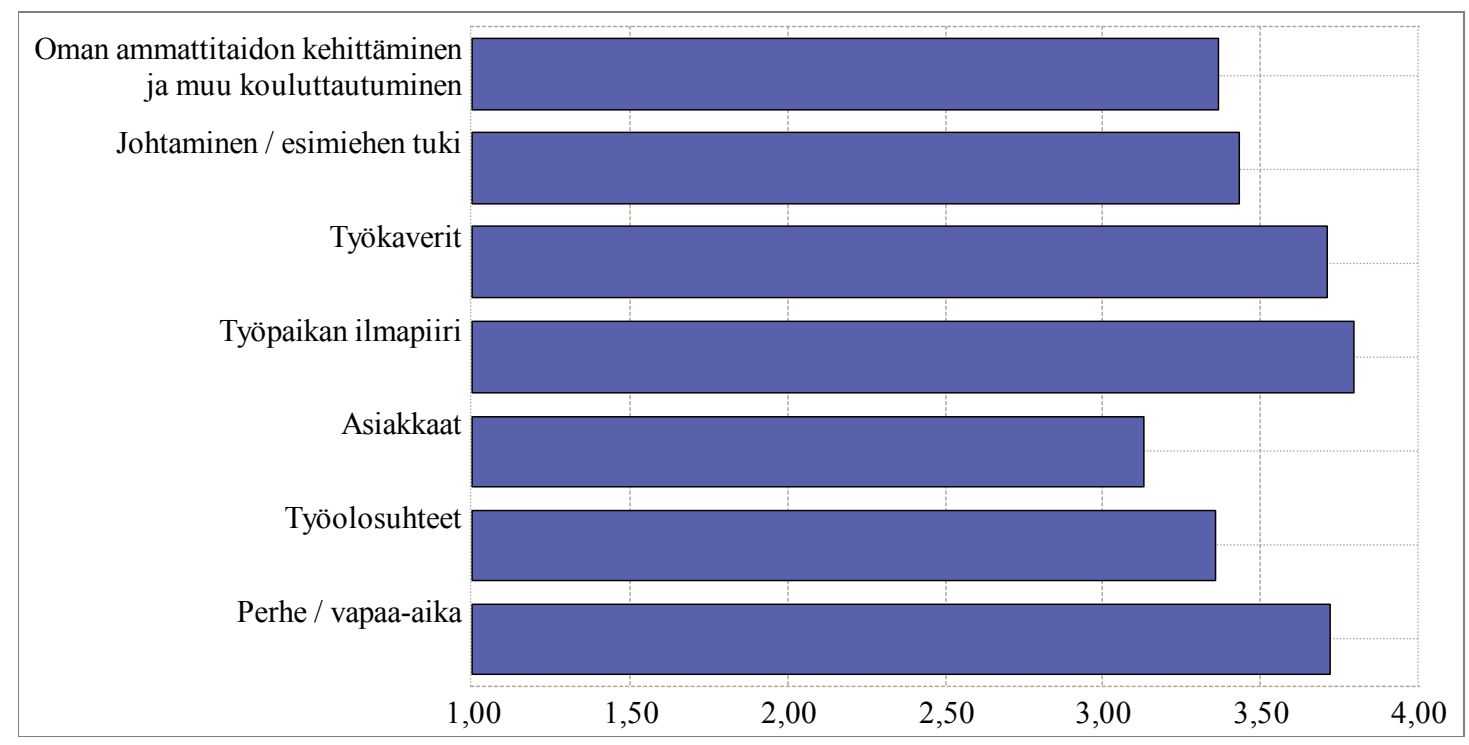

KUVIO 4. Työssä jaksamisen ja sen ylläpitämisen kannalta tärkeiksi koetut asiat $(n=196)$

\section{Johtopäätökset}

Tutkimustulosten perusteella maataloustukivalvojat ovat työssään kohdanneet erilaisia väkivalta- ja uhkatilanteita. Yleisintä olivat nimittelyt, epäasiallinen kielenkäyttö ja sanalliset uhkailut, joiden kohteeksi 72 prosenttia maataloustukivalvojista oli joutunut. Ottaen huomioon valvontatyön luonteen tarkastajan työssä joudutaan puuttumaan asiakkaiden työhön ja jopa toimeentuloon, tulos ei ollut mitenkään yllättävä. Viljelijät purkavat EU-vastaiset asenteensa ja tyytymättömyytensä maatalouspolitiikkaan sekä henkilökohtaiset työpaineet ja muut ongelmat tarkastajiin. Tällaisissa tilanteissa tarkastaja ei ole se syyllinen, vaikka hän joutuu ottamaan uhkailut ja sanomiset vastaan. Näissä tilanteissa vaaditaan tarkastajalta psykologisia taitoja hoitaa tilanne siten, ettei siitä jäisi kummallekaan osapuolelle henkistä haittaa. Tämäntyyppisestä tilanteesta voi parhaiten selviytyä kuuntelulla, mikä sinänsä ei ole helppo taito. Uhkatilanteessa tietysti kuuntelu on tärkeää, mutta myös oman rauhallisuuden säilyttäminen ja asiakasta rauhoittava keskustelu ovat tärkeitä - näitä taitoja pitäisi tarkastajillekin lisätä.

Tarkastajan fyysiseen koskemattomuuteen liittyviä tilanteita, joissa lyötiin, käytiin kiinni tai uhattiin jollain esineellä jopa aseella, oli lukumäärällisesti vähän. Jokainen tapaus, jossa työtekijän terveys tai jopa henki on uhattuna, on kuitenkin liikaa. Työn tulisi olla sellaista, että sillä ei vaaranneta kenenkään henkeä eikä työn tekeminen saisi aiheuttaa työntekijässä pelkoa. Tutkimuksen olennainen tulos oli, että viides osa (21 \%) maataloustukivalvojista oli työssään joutunut omasta mielestään välivallan tai sen uhkan uhriksi.

Tällä tutkimuksella ei ole haluttu syyllistää maataloustukivalvontojen kohteena olevia viljelijöitä. Nykyään väkivallan esiintyminen on yleistynyt kaikilla elämän aloilla. Tietysti voidaan pohtia syitä, miksi sitä esiintyy valvontatyössä ja puuttua sitä kautta asiaan. Keinona tähän voisi olla tutkimuksessakin esiin tullut asiakkaiden kouluttaminen, tiedotuksen lisääminen maataloustukiasioista ja valvonnasta, ja tätä kautta saada viljelijät ymmärtämään, että valvonta kuuluu olennaisena osana nykyiseen maataloustukijärjestelmään.

Tutkimukseni yhtenä tarkoituksena oli selvittää, millaisiin tilanteisiin maataloustukivalvojat ovat joutuneet, jotta niiden pohjalta voitaisiin paneutua ennaltaehkäisevään työhön väkivalta ja uhkatilanteiden varalle. Väkivalta tai uhkatilanne sattui valtaosassa tapauksia maatilalla joko pelto- tai eläinvalvonnan yhteydessä. Tutkimuksessa ei selvitetty tilastollisesti sitä, onko väkivallan uhriksi joutumisella riippuvuutta siitä, tehdäänkö tarkastuksia yksin vai pareittain. Kyselyn jaksamista koskevien kysymysten ja avointen vastausten kommenttien mukaan valvojat pitävät pareittain työskentelyä tärkeänä väkivalta ja uhkatilanteita ennaltaehkäisevänä tapana toimia. Koska väkivalta ja uhkatilanteita on niinkin paljon esiintynyt kuin tutkimustulokset osoittavat, mielestäni olisi turvallisempaa olisi tehdä tarkastukset pareittain. Tällöin tulee pohdittavaksi valvontaresurssien riittävyys. Toisaalta riskiksi voi tulla viljelijän ärsyyntyminen kahden valvojan tulosta tekemään valvontaa. 
Tapahtuneen väkivalta tai uhkatilanteen jälkihoitoon valvojat eivät olleet tyytyväisiä. Tämä seikka antaa pohtimisen aihetta työnantajille, koska työnantajan velvollisuus on huolehtia tästä asiasta. Työnantajilla ei ole selkeitä suunnitelmia, miten toimia esimerkiksi kriisiavun järjestämisessä. Jokaisella työnantajan edustajalla pitäisi olla selvillä, miten toimia, kun jotain vakavaa tapahtuu. Tutkimuksessa selvisi, että kaikilla maataloustukivalvojien työpaikoilla ei systemaattisesti kerätä tietoja tapahtuneista väkivalta- ja uhkatilanteista. Nämä kaikki tapaukset tulisi kirjata ylös ja pitää niistä tilastoa. Kyselyn vastauksissa ilmeni, että kaikista väkivalta- ja uhkatilanteista ei oltu kerrottu edes työnantajien edustajille.

Lähes puolet maataloustukivalvojista kamppailee jaksamisongelmien kanssa. Se on hälyttävä tieto, ja tähän tulisi reagoida sekä työnantajien että itse työntekijöidenkin. Työelämän tärkein voimavara alalla kuin alalla on työntekijät. Tässä tutkimuksessa tärkeimmiksi keinoiksi työntekijöiden jaksamiseen ja ylläpitämiseen nousivat työilmapiiri, työkaveri sekä perhe ja vapaa-aika. Työyhteisössä on oltava asiat kunnossa ja sitä on kehitettävä kaikilta osin, suurimmat haasteet kohdistuvat mielestäni johtajuuteen. Perhe ja vapaa-aika on asia mihin vain työntekijä voi vaikuttaa ei työnantaja. Vastuu työntekijöiden jaksamisesta on täten molemmilla tahoilla työnantajalla että työntekijällä.

Maataloustukivalvojien työstä tehtyä tutkimusta ja opinnäytetyötä voidaan hyödyntää valvontatyön kehittämisessä sekä Maaseutuvirastossa että jokaisessa TE-keskuksessa. Tämän pohjalta voidaan suunnitella valvontatyötä ja laatia erillisiä turvaohjeita. Tutkimustuloksia voidaan käyttää apuna valvontakoulutuksissa jota Maaseutuvirasto ja TE-keskukset järjestävät. Tämän tutkimuksen tuotoksena laadittiin maataloustukivalvontoihin turvallisuusohjeet Etelä-Savon TE-keskukselle.

\section{Kirjallisuus}

Avekki. Koulutus- ja toimintatapamalli väkivaltatilanteiden ehkäisyyn ja hallintaan. [Viitattu 15.10.2007]. Saatavissa: http://webd.savonia-amk.fi/projektit/markkinointi/avekki/.

Euroopan työterveys- ja turvallisuusvirasto 2002. Työpaikalla tapahtuva häirintä ja väkivalta. Tiedote Facts 24 . [Viitattu 21.9.2008]. Saatavissa: http://agency.osha.eu.int/publications/factsheets/24.

Euroopan työturvallisuus- ja työterveysvirasto 2003. Henkilökuntaan kohdistuvan väkivallan ehkäiseminen opetusalalla. Tiedote Facts 47. [Viitattu 21.9.2008]. Saatavissa: http://agency.osha.eu.int/publications/ factsheets/47.

Hakuopas 2008. Maaseutuviraston julkaisuja: Hakuoppaita ja ohjeita. Edita Prima Oy.

Hintikka, N \& Saarela, K.L. 2005. Väkivaltatyötapaturmat vuonna 2003. Tampereen teknillinen yliopisto. Turvallisuustekniikan laitos. Raportti 92.

Höök. J. \& Huttunen. H. 2007. Uhka- ja väkivaltatilanteiden huomioiminen osana pelastusalan työturvallisuutta. Pelastusopiston julkaisu B-sarja: Tutkimusraportti 2/2007.

ILO kansainvälinen työtoimisto. 2003. Työpaikkaväkivalta palvelualoilla ja tämän ilmiön vastaiset toimet. Kansainvälisen työjärjestön ohjeisto. Työministeriö, Sosiaali- ja terveysministeriö. Geneve. Sveitsi.

Laki Euroopan yhteisön yhteisestä maatalouspolitiikasta (N:o 1100/1994). [Viitattu 6.8.2008]. Saatavissa: http://www.finlex.fi/lains/index.html

Maaseutuvirasto 2008. Viljelijätuet [viitattu 1.9.2008]. Saatavissa: http://www.mavi.fi/fi/index/viljelijatuet.html..

NurmiOhje eläintukien valvonnasta 2007. Dnro 5232/521/2006. Maa- ja metsätalousministeriö.

Peltoalaperusteisten tukien valvontaohje 2007. Dnro 140/51/2007. Mavi.

Pirttijärvi, R. \& Pethman, P. 2006. Maataloustukivalvonnan asiakastyytyväisyyskysely 2006. Suomen Gallup Elintarviketieto Oy.

Polit D.E \& Beck C.T. 2003. Nursing Research. Principles and Methods. /th Edition. Lippinicott Williams \& Wilkins, a Wolters Kluwer Company. Philadelphia.

Työministeriö. 1994. Työpaikkaväkivallan ehkäisy. Työntekijöiden ja asiakkaiden välisten väkivaltatilanteiden hallinnan opas. Tampere

Työturvallisuuslaki (738/2002). [Viitattu 15.10.2007]. Saatavissa: http://www.finlex.fi/lains/index.html

Viljanen, P. 2006. Väkivalta - Seuraamukset ja haavoittuvuus. Helsinki: Talentum.

Yhteenvetotiedot TE-keskusten maaseutuosastojen valvontasuunnitelmista vo 2007. 19.4.2007. Maa- ja metsätalousministeriö. 